Discussion Paper No. 703

\title{
FIRST-TO-INVENT VERSUS FIRST-TO-FILE: INTERNATIONAL PATENT LAW HARMONIZATION AND INNOVATION
}

\author{
Kaz Miyagiwa
}

November 2007

The Institute of Social and Economic Research Osaka University

6-1 Mihogaoka, Ibaraki, Osaka 567-0047, Japan 


\title{
First-to-invent versus first-to-file:
}

\section{International patent law harmonization and innovation}

\author{
Kaz Miyagiwa*
}

October 29, 2007

\begin{abstract}
:
The U.S. has been under pressure to abandon the unique first-to-invent feature of its patent law for awarding patents. The opposition to reform however argues that switch to a first-to-file rule, the international norm, will undermine innovation. We evaluate this argument in a dynamic stochastic model of a patent race. The result generally supports the opposition's argument.

JEL Classification numbers: L3, O31,O34

Keywords: first-to-file, first-to-invent, patent law harmonization, innovation, U.S. patent law,

Please send correspondences to: Kaz Miyagiwa, The Institute of Social and Economic Research, Osaka University, Mihogaoka, Ibaraki, Osaka 567-0047, Japan. E-mail: kmiyagiwa@gmail.com
\end{abstract}

\footnotetext{
* The Institute of Social and Economic Research, Osaka University, and the Department of Economics, Emory University. I thank Yuka Ohno and seminar participants at Hitotsubashi and Kobe Universities for comments. A research grant from Microsoft's academic research program is gratefully acknowledged. Any opinion expressed are those of the author's.
} 


\section{First-to-invent versus first-to-file:}

\section{International patent law harmonization and innovation}

Abstract: The U.S. has been under pressure to abandon the unique first-to-invent feature of its patent law for awarding patents. The opposition to reform however argues that switch to a firstto-file rule, the international norm, will undermine innovation. We evaluate this argument in a dynamic stochastic model of a patent race. The result generally supports the opposition's argument.

\section{Introduction}

Despite recent successes in harmonizing patent law internationally, the U.S. patent law still retains some unique features. One such feature is the first-to-invent rule. ${ }^{1}$ When two people apply for a patent on the same invention, virtually all other governments in the world issue a patent to the person who filed his application first. In the U.S., however, determination is made as to priority of invention and a patent is awarded to the person who can demonstrate to have discovered the invention first. ${ }^{2}$ Although the U.S. has repeatedly demonstrated its willingness to conform to the international norm, the opposition remains strong. ${ }^{3}$

The opposition to patent law reform in the U.S. embraces two arguments. One is that the first-to-invent feature of the U.S. patent law protects small inventors who may take longer to prepare patent applications and who therefore would lose to major corporate inventors in a

\footnotetext{
${ }^{1}$ Another prominent feature of the U.S. patent law was its confidential filing system. Until the Intellectual Property and Communications Omnibus Reform Act of 1999, all patent applications were kept secret until patents were granted. This has since been changed and now applications are published 18 months after their filing dates, the international norm (see Aoki and Prusa 1996, and Aoki and Spiegel 2003). However, inventors choosing not to file for a foreign patent can opt for non-publication of their applications, leaving open the possibility of notorious "submarine" patents; see Graham and Mowrey (2004).

${ }^{2}$ The exception is the Philippines, which uses a first-to-invent rule due to its colonial legacy with the U.S.

${ }^{3}$ A first-to-file rule is contained in the Patent Act of 2005, introduced by Rep. Lamar Smith, R-Texas. This bill however, has not been approved, as of this writing. Also at the 2007 G8 Summit meeting in Germany, President George W. Bush formally stated his support for a first-to-file rule.
} 
first-to-file system. ${ }^{4}$ However, Lerner (2003) calls this argument spurious, noting that the recent patent law reform in the U.S. has created a new provisional patent application, which is much simpler to file. Further, in the U.S., disputes over priority of invention are settled in a legal proceeding called interference, which involves examining laboratory logbooks, establishing dates for prototypes, and so on at a hearing before the USPTO (U.S. Patent and Trademark Office) Board. ${ }^{5}$ In one estimate the adjudication of the average interference costs over one hundred thousand dollars (Kingston 1992). Since the costs of interferences are borne equally by the parties involved, a first-to-invent rule does not necessarily protect financially constrained small inventors. Cohen and Ishii (2005) find in an empirical study that interference does not help small individual inventors against large corporate inventors. Thus, concludes Lerner (2003), "the greatest beneficiary from the first-to-invent system is the small subset of the patent bar that specializes in international law."

A second argument employed by the opposition group is that a first-to-file rule will undermine innovation, because a patent issues not to the inventor but to the individual who is fastest in filing a patent application. To bolster this argument the opposition adduces the undeniable fact that the U.S. has led the world in inventions for more than a century and attributes that remarkable record to the first-to-invent feature of the patent law that the nation has had since $1836 .^{6}$

The objective of the present paper is to evaluate the argument that a first-to-file rule

\footnotetext{
${ }^{4}$ See, e.g., Stephenson (2005).

${ }^{5}$ See Cohen and Ishii (2005) for a detailed study of the interference process.

${ }^{6}$ For example, one writes "It should be understood that it is because the U.S. has a first to invent structure and the rest of the world has a first to file structure that the U.S. is the production and employment machine that it is." (See $\mathrm{http} / /$ www.piausa.org/layout/set/print/patent_reform_issue.)
} 
undermines innovation relative to a first-to-invent rule. In doing so, we focus on two types of risks faced by an inventor. A first is the risk of losing his invention to someone who discovers it later. First-to-invent eliminates this risk, giving an inventor time and security to experiment with and perfect his invention. However, first-to-invent can also expose an inventor to another risk, the risk that he may be wasting resources trying to discover the same invention that has already been discovered. First-to-invent can increase this risk by allowing inventors to take more time before filing for a patent. Due to these two risks it is not a priori clear whether firstto-invent is more conducive to invention relative to first-to-file.

To study how these risks affect the incentives to invent, we develop a dynamic model of a patent race. We assume a stationary environment, in which two firms engage in a patent race over an infinite time horizon. A firm's discovery date is stochastic, and depends on the level of investment in R\&D a firm makes at the beginning, e.g., the size of the lab it builds or the type of equipment it installs. It is natural to expect that, the greater the level of investment in $\mathrm{R} \& \mathrm{D}$, the greater is probability of discovery.

Once having made a discovery, a firm faces two options. One is to file immediately for a patent. The other is to improve the quality of the invention before filing for a patent. A strong novelty requirement or scope protection is assumed, so if there is a patent on the unimproved invention the improved version will not be patented separately.

The model thus has two stages. In the first stage, each firm chooses a level of investment in R\&D, which determines its probability of discovery in the second-stage game. This is consistent with the finding of Cohen and Ishii (2005) that most patent races are among major corporate research laboratories chasing well-defined research topics, where initial setups 
are of utmost importance in conducting research.

The second stage consists of an infinite number of periods. In each period, nature first chooses "success" or "failure" for each firm according to the firm's probability of discovery determined in stage 1 . The firm can, by incurring some cost (say, of operating the lab equipment), learn what nature chose for it, but not what it chose for the rival. Thus there is an informational asymmetry in the model. Conditional on having made the invention, a firm decides whether to file for a patent immediately or improve the quality of the invention before filing. The improvement process is not stochastic but takes time.

Our results can now be summarized. In first-to-invent, the model has the unique equilibrium outcome in which both firms choose to improve the invention. First-to-file results in the same equilibrium outcome at certain parameter values, but admits This also is an equilibrium in first-to-file, in which case the two rules are equally effective in inducing R\&D efforts. Depending on the parameter values, however, first-to-file can results in firms filing for a patent immediately upon discovery. In the latter equilibrium outcome, we find firms investing less in R\&D efforts in first-to-file. Thus, our analysis lends some support to the claim of the opposition to patent law reform in the U.S.

The literature has already examined various aspects of patent law; for example, patent length and breath (Nordhaus 1969, Gilbert and Shapiro 1990, Klemperer 1990, O’Donoghue, Scotchmer and Thisse 1998), novelty requirements (Scotchmer and Green 1990), patent renewal rules (Scotchmer 1999, Cornelli and Schankerman 1999), and pre-grant patent publication (Aoki and Prusa 1996, Aoki and Spiegel 2003). However, there is, to the best of the author's knowledge, no formal analysis of the first-to-invent feature of the U.S. patent law, with 
the exception of Scotchmer and Green (1990). Their work however differs significantly from the work on hand both in focus and in setup.

Scotchmer and Green (1990) consider two firms racing to improve some base-level technology already patented to a third-party. There are two innovations: intermediate and final. Two features set their work apart from ours. First, probability of innovation is exogenous so the relative effect of the two patent rules on $R \& D$ efforts is unexamined. More importantly, in their model there is complete information; a firm knows it when the rival discovered the intermediate innovation, whether it is patented or not. So, unlike in this paper, firms do not face the risk of wasting resources trying to discover the invention that has already been made.

As regards the focus, Scotchmer and Green (1990) are more concerned with the varying degrees of novelty requirements of patent law. In their model, patenting the intermediate invention reveals its content to the rival firm, enabling the rival to bypass the intermediate step, thereby accelerating discovery of the final innovation. If the novelty requirement is so strong that the intermediate innovation infringes the existing patent on the base-level technology, however, the intermediate innovation is not patented, thereby retarding discovery of the final innovation. Even with a weaker novelty requirement, the inventor may forgo patenting the intermediate invention to force the rival out of competition. However, such a shakeout is less likely to arise in first-to-file because the rival could get a patent on the intermediate innovation if the inventor does not. Scotchmer and Green (1990) thus conclude that first-to-file accelerates discovery of the final innovation relative to first-to-invent in a broader set of parameter values they consider.

The remainder of the paper is organized in five sections. The next section gives a more 
detailed description of the model. Sections 3 and 4 are devoted to the study of first-to-file, and first-to-invent, respectively. In Section 5 we compare the incentives to innovate under these two rules. Section 6 concludes.

\section{Environment}

We consider an $R \& D$ race between two firms, which are symmetric and designated by $\mathrm{j}$ $=\mathrm{A}, \mathrm{B}$. The model has two stages. In the first stage, firms simultaneously choose levels of investment in $\mathrm{R} \& \mathrm{D}$ at cost $\mathrm{k}_{\mathrm{j}}$, knowing that this investment level determines a firm's probability of discovery in the second stage. The second stage has an infinite number of periods, running from 1 . In each period, firms simultaneously decide whether or not to conduct R\&D. If they do, each incurs the operating cost $\mathrm{c}$, and discovers the invention with probability $\mathrm{p}_{\mathrm{i}}\left(\mathrm{k}_{\mathrm{i}}\right)$ during that period. Without conducting $\mathrm{R} \& \mathrm{D}$, firms have no chance of a discovery.

As outlined in section 1, once having discovered the invention, the inventor can file for a patent immediately or choose to improve the quality of the invention. The improvement process is assumed deterministic but time-consuming. We assume for simplicity that it takes one period to complete it. Whichever option a firm chooses, a patent is issued at the end of the period in which it files an application. The invention has value $\mathrm{m}>0$ without improvement and value $M$ with improvement, both evaluated at the time of discovery. We assume $M>m$; otherwise no firm would be interested in the improvement. We also assume strong novelty or scope requirements of patent law so that the improved version cannot be patented separately if a patent has already been issued on the original invention. Therefore, in the absence of rivalry the inventor would always choose to improve the invention. However this need not be the case 
when firms compete. More importantly, unlike Scotchmer and Green (1990), we assume incomplete information; unless the inventor gets a patent, the rival does not know that there has been a discovery.

The final assumption we make is that the firms incur no cost other than the $R \& D$ costs. This ensures that our results are not influenced by the difference in non-R\&D-related costs such as patent application fees and legal and court fees as may arise in interference proceedings, and allows us to focus on the issue on hand.

\section{First-to-file}

We begin with a first-to-file rule. We first specify the payoffs. In each period of the second-stage game nature's choice gives rise to potentially four possible states. Consider first the state in which nature assigns "success" to both firms. In this case, depending on what the firms do next, there are three cases to consider. First, if both firms file for a patent immediately, each firm gets a patent with equal probability; therefore, the expected payoff is $\mathrm{m} / 2$ per firm. ${ }^{7}$ Likewise, if both choose to improve their inventions, the expected payoff is $\mathrm{M} / 2$ per firm. A third is a case in which firms take different actions. For example, if A files immediately but B waits, a patent issues to A, so A gets $\mathrm{m}$ and B zero payoffs.

Consider next the second state of nature, in which only A makes a discovery. By filing immediately for a patent, A gets a patent valued $\mathrm{m}$. On the other hand, if A waits one period to improve, B may discover the invention the following period and beat A to the patent office,

\footnotetext{
${ }^{7}$ When an application for a patent is prepared and filed depends on the lawyers who are handling it. Thus, the inventor may not have full control over when an application is filed. Further, if two applications are filed on the same invention on the same day in Japan, two applicants are asked to negotiate with each other and file a new application under one name.
} 
reducing A's payoff to $\mathrm{m} / 2$. The third state of nature occurs when $\mathrm{B}$ alone makes a discovery, and is symmetric to the second state. The fourth and final state occurs when neither firm discovers the invention, in which case no firms take further action until the following period.

We are now ready to solve the game. We focus on a stationary equilibrium. Formally, a firm's strategy in the second stage game is an infinite sequence of actions (file immediately for a patent or wait one period to do so) for each period $t \geq 1$, conditional on having discovered the invention and the rival not having awarded a patent. A strategy is stationary if it specifies a time-independent action for all $\mathrm{t} \geq 1$.

\section{A. Equilibrium in which the invention is improved}

We begin with the equilibrium, in which upon discovery each firm waits one period to improve the invention before filing for a patent. In this case, the firms do not know for sure whether the rival discovered the invention during the previous period. However, the firm forms beliefs as to the probability that the rival had made the discovery in the previous period. Thus, the firms play a game of incomplete information, and we look for a Bayesian-Nash equilibrium, according to which the equilibrium strategies are sequentially rational, given beliefs, while beliefs are Bayes-consistent with the strategies on the equilibrium path.

Let $\mathrm{E}_{\mathrm{A}}\left(\mathrm{p}_{\mathrm{B}} ; \mathrm{t}\right)$ denote $\mathrm{A}$ 's period-t beliefs as to the probability that $\mathrm{B}$ discovered the invention in the previous period, conditional on non-issuance of a patent to $\mathrm{B}$ to date. For $\mathrm{t} \geq 2$,

this belief must equal the value of $p_{B} B$ chose in the first stage. For $t=1, E_{A}\left(p_{B}, 1\right)=0$ because there is no previous period in which to make a discovery. 
Suppose that $A$ discovers the invention in period $t \geq 2$. A then improves it and files for a patent in period $t+1$. The equilibrium value of the invention to $\mathrm{A}$ is $\mathrm{M}$ if $\mathrm{B}$ did not discover the invention in period $t$, a probability $\left(1-\mathrm{p}_{\mathrm{B}}\right)$ event, and $\mathrm{M} / 2$ if $\mathrm{B}$ did, because each inventor is equally likely to get a patent on his invention. Thus, the equilibrium expected value of the invention to $\mathrm{A}$ is

$$
\left(1-p_{B}\right) M+p_{B} M / 2=\left(1-p_{B} / 2\right) M=V .
$$

This value is of course conditional on B not having discovered the invention in period $t-1$. However, A does not know whether B made the discovery in $\mathrm{t}-1$, so A cannot condition its decision to conduct on R\&D on B's discovery in the previous period. Thus, the equilibrium value of conducting $R \& D$ in period $t$ is

$$
\left(1-p_{B}\right) p_{A} V-c,
$$

that is, getting $\mathrm{V}$ is weighted by the probability that A discovers the invention in period $\mathrm{t}$ and $\mathrm{B}$ did not in period $\mathrm{t}-1 .^{8}$ A reaches period $\mathrm{t}$ without the invention, conditional on not having discovered it from period 1 through period $\mathrm{t}-1$, a probability $\left(1-\mathrm{p}_{\mathrm{A}}\right)^{\mathrm{t}-1}$ event, and conditional also on $\mathrm{B}$ not having made the discovery through period $\mathrm{t}-2$, a probability $\left(1-\mathrm{p}_{\mathrm{B}}\right)^{\mathrm{t}-2}$ event. The difference in probability can be understood by recalling that A can observe whether B has made the discovery through period $\mathrm{t}-2$ but not the last period because of the one-period information lag.

\footnotetext{
${ }^{8}$ With probability $\mathrm{p}_{\mathrm{B}} \mathrm{B}$ had made a discovery in the previous period and files for a patent in period $\mathrm{t}$. In that case A's equilibrium payoff is zero since $\mathrm{A}$ is not filing for a patent in period $\mathrm{t}$.
} 
The above argument does not apply exactly to period 1 because there are no previous periods. For $\mathrm{t}=1$ the expected profit is just $\mathrm{p}_{\mathrm{A}} \mathrm{V}-\mathrm{c}$, because in $\mathrm{t}=1 \mathrm{~A}$ knows that $\mathrm{B}$ did not make the invention in the previous period. Making use of these facts, and letting $\delta$ denote the discount factor, we can write A's expected profit in the second stage as follows:

$$
\begin{aligned}
\left(\mathrm{p}_{\mathrm{A}} \mathrm{V}-\mathrm{c}\right)+\delta\left(1-\mathrm{p}_{\mathrm{A}}\right)\left[\left(1-\mathrm{p}_{\mathrm{B}}\right) \mathrm{p}_{\mathrm{A}} \mathrm{V}-\mathrm{c}\right] \\
\quad+\delta^{2}\left(1-\mathrm{p}_{\mathrm{A}}\right)^{2}\left(1-\mathrm{p}_{\mathrm{B}}\right)\left[\left(1-\mathrm{p}_{\mathrm{B}}\right) \mathrm{p}_{\mathrm{A}} \mathrm{V}-\mathrm{c}\right] \\
\quad+\delta^{3}\left(1-\mathrm{p}_{\mathrm{A}}\right)^{3}\left(1-\mathrm{p}_{\mathrm{B}}\right)^{2}\left[\left(1-\mathrm{p}_{\mathrm{B}}\right) \mathrm{p}_{\mathrm{A}} \mathrm{V}-\mathrm{c}\right]+\ldots
\end{aligned}
$$

Turning to the first stage, firms simultaneously choose levels of investment in R\&D, which determine the value of the $p_{j}$ above. The notation simplifies however, if we let firms directly choose probability $\mathrm{p}_{\mathrm{j}} \in[0,1)$ instead of investment levels. We thus let $\mathrm{k}\left(\mathrm{p}_{\mathrm{i}}\right)$ denote the investment cost, which satisfies the following properties: $\mathrm{k}(0)=0, \mathrm{k}^{\prime}>0, \mathrm{k}^{\prime}>0, \mathrm{k}^{\prime}(0)=\mathrm{k}(1)=$ $\infty$, where primes denote differentiation. Now, collecting terms, substituting for $\mathrm{V}$, and subtracting $\mathrm{k}\left(\mathrm{p}_{\mathrm{A}}\right)$, we arrive at the following expression for the expected profit to firm $\mathrm{A}$ in the first stage:

$$
\frac{p_{A}\left(1-p_{B} / 2\right) M-\left[1+\delta p_{B}\left(1-p_{A}\right)\right] c}{1-\delta\left(1-p_{A}\right)\left(1-p_{B}\right)}-k\left(p_{A}\right) .
$$

A takes $\mathrm{p}_{\mathrm{B}}$ as given and chooses $\mathrm{p}_{\mathrm{A}}$ to maximize (2). The first-order condition is arranged to yield

$$
\begin{aligned}
& \left(1-\mathrm{p}_{\mathrm{B}} / 2\right) \mathrm{M}\left[1-\delta\left(1-\mathrm{p}_{\mathrm{A}}\right)\left(1-\mathrm{p}_{\mathrm{B}}\right)-\delta \mathrm{p}_{\mathrm{A}}\left(1-\mathrm{p}_{\mathrm{B}}\right)\right] \\
& +\delta\left\{\mathrm{p}_{\mathrm{B}}\left[1-\delta\left(1-\mathrm{p}_{\mathrm{A}}\right)\left(1-\mathrm{p}_{\mathrm{B}}\right)\right]+\left(1-\mathrm{p}_{\mathrm{B}}\right)\left[1+\delta \mathrm{p}_{\mathrm{B}}\left(1-\mathrm{p}_{\mathrm{A}}\right)\right]\right\} \mathrm{c}
\end{aligned}
$$




$$
\begin{aligned}
& -\left[1-\delta\left(1-\mathrm{p}_{\mathrm{A}}\right)\left(1-\mathrm{p}_{\mathrm{B}}\right)\right]^{2} \mathrm{k}^{\prime}\left(\mathrm{p}_{\mathrm{A}}\right) \\
& =\left(1-\mathrm{p}_{\mathrm{B}} / 2\right) \mathrm{M}\left[1-\delta\left(1-\mathrm{p}_{\mathrm{B}}\right)\right]+\delta \mathrm{c}-\left[1-\delta\left(1-\mathrm{p}_{\mathrm{A}}\right)\left(1-\mathrm{p}_{\mathrm{B}}\right)\right]^{2} \mathrm{k}^{\prime}\left(\mathrm{p}_{\mathrm{A}}\right)=0,{ }^{9}
\end{aligned}
$$

which defines A's best-response function $r_{1}{ }^{*}\left(p_{B}\right)$, where the subscript 1 implies that firms wait one period to improve the invention. The rival's best-response function obtains similarly. The Nash equilibrium is a pair of probabilities $\left(\mathrm{p}_{\mathrm{A}}, \mathrm{p}_{\mathrm{B}}\right)$ that are best responses to each other. Focusing on the symmetric equilibrium, we denote the common equilibrium probability by $\mathrm{p}_{1}^{*}$

We next check a firm's incentive to deviate. Suppose that A, having discovered the invention in any period $\mathrm{t} \geq 2$, files for a patent in period $\mathrm{t}$. A's payoff is $\mathrm{m}$, conditional on B not having discovered the invention in period $\mathrm{t}-1 .{ }^{10}$ If $\mathrm{B}$ made a discovery previously, $\mathrm{B}$ also files for a patent in period $\mathrm{t}$ according to the equilibrium strategy, so A's payoff is $\mathrm{m} / 2{ }^{11}$ Since $\mathrm{B}$ would have discovered the invention with probability $\mathrm{p}_{\mathrm{B}}$, the expected payoff to A from a deviation equals

$$
\mathrm{p}_{\mathrm{B}} \mathrm{m} / 2+\left(1-\mathrm{p}_{\mathrm{B}}\right) \mathrm{m}=\left(1-\mathrm{p}_{\mathrm{B}} / 2\right) \mathrm{m} \text {. }
$$

In comparison, the equilibrium strategy yields zero payoff to A if B discovered in the previous period and $V=\left(1-p_{B} / 2\right) M$ if $B$ did not. Since $B$ makes a discovery with probability $p_{B}$, the

\footnotetext{
${ }^{9}$ We assume the second-order condition holds at the optimum. It is guaranteed if $\mathrm{k}^{\prime}\left(\mathrm{p}_{\mathrm{j}}\right)$ rises sharply enough.

${ }^{10}$ Even if $\mathrm{B}$ discovers the invention in the current period, it will not file for a patent till the next period in equilibrium.

${ }^{11}$ We assume that an interference process does not favor either firm despite the difference in quality between the two applications.
} 
equilibrium payoff to $A$ is $\left(1-p_{B}\right)\left(1-p_{B} / 2\right) M$. Therefore, $A$ has no incentive to deviate if and only if

$$
\left(1-p_{B}\right)\left(1-p_{B} / 2\right) M \geq\left(1-p_{B} / 2\right) m,
$$

or

$$
\left(1-p_{B}\right) M \geq m
$$

The first period differs in that B could not have discovered the invention earlier. Therefore, deviating in $\mathrm{t}=1$, A gets $\mathrm{m}$, which is compared with the equilibrium payoff, $(1-$ $\left.\mathrm{p}_{\mathrm{B}}\right) \mathrm{M}$. Thus, (4) is valid for preventing deviations at $\mathrm{t}=1$ as well. Using symmetry, we write the no-deviation condition for both firms as

$$
\left(1-\mathrm{p}_{1}^{*}\right) \mathrm{M} \geq \mathrm{m}
$$

Further, $\mathrm{p}_{1}^{*}$ being the symmetric equilibrium probability, A has no incentive to deviate from $\mathrm{p}_{1}{ }^{*}$ when choosing an R\&D investment level in the first stage as long as (5) is satisfied. Similarly, B has no such incentive, either. We thus conclude that investing $\mathrm{p}_{1}{ }^{*}$ in the first stage and waiting one period to file for a patent after discovering the invention is an equilibrium strategy if (5) is satisfied.

\section{B Equilibrium in which firms file immediately for a patent}

We consider next the equilibrium in which both firms file for a patent immediately. Supposing that $A$ discovers the invention in period $t \geq 1$. The equilibrium payoff is $m$ if $B$ does not make a discovery in period $\mathrm{t}$ but $\mathrm{m} / 2$ if it did because then each can get a patent with equal probability. Thus, the expected payoff is 


$$
\mathrm{v}=\left(1-\mathrm{p}_{\mathrm{B}}\right) \mathrm{m}+\mathrm{p}_{\mathrm{B}} \mathrm{m} / 2=\left(1-\mathrm{p}_{\mathrm{B}} / 2\right) \mathrm{m} \text {. }
$$

In this equilibrium, when a patent was not issued to B in the previous period, $\mathrm{A}$ believes with certainty that $\mathrm{B}$ did not discover the invention in that period. That is, $\mathrm{E}_{\mathrm{A}}\left(\mathrm{p}_{\mathrm{B}}, \mathrm{t}\right)=0$ for all $\mathrm{t}$ $\geq 1$, conditional on a patent not having issued to the rival. Then, A can condition its decision to conduct $\mathrm{R} \& \mathrm{D}$ in the current period on a patent not having issued to B previously. Thus, A avoids the risk of duplicating the invention made by the rival. The expected equilibrium value for $A$ of conducting $R \& D$ in period $t$ is therefore $p_{A} v-c$. Since $A$ conducts $R \& D$ in period $t$ only if neither firm made the discovery between period 1 and period $t-1$,

We can now write A's expected profit as:

$$
\begin{aligned}
\left(\mathrm{p}_{\mathrm{A}} \mathrm{v}-\mathrm{c}\right) & +\delta\left(1-\mathrm{p}_{\mathrm{A}}\right)\left(1-\mathrm{p}_{\mathrm{B}}\right)\left(\mathrm{p}_{\mathrm{A}} \mathrm{v}-\mathrm{c}\right) \\
& +\delta^{2}\left(1-\mathrm{p}_{\mathrm{A}}\right)^{2}\left(1-\mathrm{p}_{\mathrm{B}}\right)^{2}\left(\mathrm{p}_{\mathrm{A}} \mathrm{v}-\mathrm{c}\right)+\ldots
\end{aligned}
$$

Summing and subtracting the cost of $R \& D$ investment, we obtain the first-stage expected profit to A:

$$
\frac{p_{A}\left(1-p_{B} / 2\right) m-c}{1-\delta\left(1-p_{A}\right)\left(1-p_{B}\right)}-k\left(p_{A}\right)
$$

A maximizes this with respect to $\mathrm{p}_{\mathrm{A}}$, given $\mathrm{p}_{\mathrm{B}}$. The first-order condition:

$$
\begin{aligned}
& \mathrm{m}\left(1-\mathrm{p}_{\mathrm{B}} / 2\right)\left[1-\delta\left(1-\mathrm{p}_{\mathrm{B}}\right)\right]+\delta\left(1-\mathrm{p}_{\mathrm{B}}\right) \mathrm{c} \\
& -\left[1-\delta\left(1-\mathrm{p}_{\mathrm{A}}\right)\left(1-\mathrm{p}_{\mathrm{B}}\right)\right]^{2} \mathrm{k}^{\prime}\left(\mathrm{p}_{\mathrm{A}}\right)=0
\end{aligned}
$$

implicitly defines A's best response function $\mathrm{r}_{0}\left(\mathrm{p}_{\mathrm{B}}\right)$, where subscript " 0 " reminds us that firms file for a patent without no (zero) improvement on the invention. By symmetry, putting $\mathrm{p}_{\mathrm{A}}=\mathrm{p}_{\mathrm{B}}$ 
in (7), yields the symmetric Nash equilibrium levels of investment (probabilities), which we denote by $\mathrm{p}_{0}^{*}$.

Now consider a deviation. Suppose that, having discovered the invention in period $\mathrm{t}, \mathrm{A}$ chooses to improve the invention. If $\mathrm{B}$ also makes a discovery in period $\mathrm{t}, \mathrm{B}$ files immediately for a patent and is awarded a patent in first-to-file, so a deviation yields zero profit to A. On the other hand, if B does not discover the invention in period t, A's payoff depends on whether or not $\mathrm{B}$ will make a discovery in period $\mathrm{t}+1$. If $\mathrm{B}$ does, $\mathrm{B}$ files immediately for a patent, so A's expected profit will be $\mathrm{M} / 2$. If $\mathrm{B}$ does not, however, A will earn $\mathrm{M}$ instead of $\mathrm{m}$. Thus, the payoff to A from a deviation would be $\left(1-p_{B}\right)\left[p_{B} M / 2+\left(1-p_{B}\right) M\right]$. If this is less than the equilibrium payoff, that is, if

$$
\mathrm{p}_{\mathrm{B}} \mathrm{m} / 2+\left(1-\mathrm{p}_{\mathrm{B}}\right) \mathrm{m} \geq\left(1-\mathrm{p}_{\mathrm{B}}\right)\left[\mathrm{p}_{\mathrm{B}} \mathrm{M} / 2+\left(1-\mathrm{p}_{\mathrm{B}}\right) \mathrm{M}\right]
$$

then A has no incentive to deviate. Simplifying and using symmetry, we can rewrite the above inequality as:

$$
\mathrm{m} \geq\left(1-\mathrm{p}_{0}^{*}\right) \mathrm{M}
$$

We have obtained:

Proposition 1: In first-to-file,

(A) the model possesses the equilibrium in which both firms choose to improve the quality of the invention. In it, the equilibrium probability $\mathrm{p}_{1}{ }^{*}$ satisfies

$$
\mathrm{m} \leq\left(1-\mathrm{p}_{1}^{*}\right) \mathrm{M}
$$


(B) the model possesses the equilibrium in which both firms choose to file immediately for a patent on the original invention. In it the equilibrium probability $\mathrm{p}_{0} *$ satisfies

$$
\mathrm{m} \geq\left(1-\mathrm{p}_{0}^{*}\right) \mathrm{M}
$$

Proposition 1A says that firms choose to improve the invention if $\mathrm{m} \leq\left[1-\mathrm{p}_{1}{ }^{*}\right] \mathrm{M}$; i.e., if the value of the improved invention is greater than that of the original invention, discounted by the probability of discovery by the rival. An analogous interpretation is made as to Proposition $1 \mathrm{~B}$. Finally, it is straightforward to check that there is no asymmetric equilibrium in first-tofile as the firm has no incentive to postpone filing if the rival files immediately for a patent.

\section{C. A comparison of equilibrium $R \& D$ efforts}

We now compare the levels of investment in $R \& D$ in two types of equilibrium outcomes. The next proposition gives the result (the proof is in the appendix).

Proposition 2: $\mathrm{p}_{1}{ }^{*}>\mathrm{p}_{0}{ }^{*}$; that is, in first-to-file firms invest more when they improve the invention than when they file immediately for a patent.

This seems intuitive. Since the improved invention is more valuable, firms exert more effort in R\&D in the equilibrium in which they can improve the invention.

In Figure 1 we present a numerical example, where we set $\delta=0.9, \mathrm{M}=100, \mathrm{~m}=60, \mathrm{c}=$ 10 and $\mathrm{k}=10 \mathrm{p}_{\mathrm{A}} /\left(1-\mathrm{p}_{\mathrm{A}}\right)$. The best-response functions closer to the origin correspond to the 
equilibrium in which firms file immediately and those further out to the equilibrium in which firms improve the invention. The equilibrium probability values are $\mathrm{p}_{1}^{*}=0.62$ and $\mathrm{p}_{0} *=0.53$, which is consistent with Proposition 2.

The next question is what determines which equilibrium to occur. Proposition 2 implies that $1-\mathrm{p}_{0}^{*}>1-\mathrm{p}_{1} *$. Therefore, if

$$
\mathrm{m} / \mathrm{M} \geq 1-\mathrm{p}_{0}^{*}>1-\mathrm{p}_{1}^{*}
$$

1 firms file for a patent right away. On the other hand, if

$$
1-\mathrm{p}_{0}^{*}>1-\mathrm{p}_{1}^{*}>\mathrm{m} / \mathrm{M}
$$

firms improve the invention. Finally, if

$$
1-\mathrm{p}_{0} *>\mathrm{m} / \mathrm{M}>1-\mathrm{p}_{1}^{*}
$$

the both conditions in Proposition 1 fail, implying there is no equilibrium in pure strategies. However, there is an equilibrium in mixed strategies in the second-stage game; i.e., firms randomize between filing immediately and waiting one period to file for a patent. Denote $\mathrm{p}_{\mathrm{m}}{ }^{*}$ is the symmetric equilibrium level of investment in R\&D when firms randomize in this fashion, In each period $t \geq 1$, the mixed-strategy payoff from improving the invention is less than the corresponding payoff with pure strategies, and the mixed-strategy payoff from filing for a patent immediately upon discovery is greater than its counterpart from the pure-strategy game. Therefore, given that firms invest more in $R \& D$ when expecting a greater profit in the second-stage game, $\mathrm{p}_{\mathrm{m}}{ }^{*}$, the equilibrium level of investment in R\&D using mixed strategies, is less than $\mathrm{p}_{1}^{*}$ and greater than $\mathrm{p}_{0} *$. Therefore, we have (see the appendix for details) 
Lemma 1: $\mathrm{p}_{0}{ }^{*}<\mathrm{p}_{\mathrm{m}}{ }^{*}<\mathrm{p}_{1}{ }^{*}$

Thus, whenever firms choose to file immediately for a patent with positive probability, firms invest less in $R \& D$ than when they choose to improve the invention with certainty.

\section{First-to-invent}

We next turn to first-to-invent. The game structure is the same as in the previous section. Again, focusing on a stationary equilibrium, begin with the equilibrium, in which, conditional on having discovered the invention, each firm waits one period to improve the invention. Given the structure of the model the expected payoff is exactly the same as with first-to-file, given in (1). It is recalled that the symmetric equilibrium probability is denoted by $\mathrm{p}_{1}^{*}$.

We check if a firm has a profitable deviation. Suppose that A deviates and files for a patent immediately upon discovery in period $\mathrm{t}$, say. If $\mathrm{B}$ also discovers the invention in period $\mathrm{t}$, with first-to-invent B will be able to challenge A's priority of invention in period $t+1$. Given that an interference process does not favor either firm, A can defend its priority in an interference proceeding only with probability $1 / 2$. Hence, the deviation reduces A's payoff to $\mathrm{m} / 2$ from $\mathrm{M} / 2$, the equilibrium payoff. On the other hand, if $\mathrm{B}$ does not discover the invention in period $\mathrm{t}$, a deviation yields $\mathrm{m}$ instead of the equilibrium payoff $\mathrm{M}$. In each case, the deviation reduces A's profit, and hence A has no incentive to deviate upon discovery. 
Consider next the equilibrium in which both firms file for a patent immediately. The expected payoff to $\mathrm{A}$ is given in (6) and the first-order condition in (7). The symmetric equilibrium is denoted by $\mathrm{p}_{0}{ }^{*}$ as before.

Now suppose that A deviates and improves the invention, upon discovery in period t. If $\mathrm{B}$ also discovers the invention in period $\mathrm{t}, \mathrm{B}$ files for a patent on the unimproved invention. However, A can contest B's claim of priority of invention in an interference hearing the following period, thereby raising A's expected payoff from $\mathrm{m} / 2$ to $\mathrm{M} / 2 .^{12}$ On the other hand, if $\mathrm{B}$ did not discover the invention in period $\mathrm{t}$, a patent will be issued to $\mathrm{A}$, the first inventor, regardless of what happens to B later, thereby raising A's payoff from $\mathrm{m}$ to M. In either case, a deviation is profitable for A, and hence filing immediately for a patent is not an equilibrium strategy in first-to-invent. We have obtained

Proposition 3: In the unique equilibrium with first-to-invent, firms always improve the invention before filing for a patent.

Finally, the model does not possess asymmetric equilibrium outcomes because filing for a patent before the rival offers no advantage in first-to-invent.

\section{A comparison}

\footnotetext{
12 Strictly speaking this is not an entirely correct statement ; B may earn profit during the one period before it is challenged. However, as this profit will be surrendered to A, the true patent holder, this strengthens our case.
} 
We are now ready to examine whether first-to-invent furthers innovation relative to first-to-file as claimed by the opposition to reform in the U.S. As we showed above, the two rules yield the identical outcome when first-to-file induces firms to improve the invention; that is, if the value of the patent on the improved invention is sufficiently large. The two rules differ when first-to-file induces firms to file for a patent. The following results straightforwardly from Propositions 1-3 and Lemma 1.

Proposition 4: (A) If in first-to-file firms improve the invention, the two rules are equally conducive to R\&D. (B) If in first-to-file firms file immediately for a patent (with positive probability), first-to-invent induces more efforts in $\mathrm{R} \& \mathrm{D}$ than first-to-file.

In our model firms prefer the improved version to the original and would exert more effort in R\&D if they could agree to commit to taking time to improve. Although such a commitment is impossible to make, first-to-invent guarantees such a result by eliminating the risk of losing the invention to a latecomer. In contrast, first-to-file does not provide such guarantee. As we saw, if the improvement results in insufficient value added, firms choose to file immediately for a patent in the fear that it will lose patent rights to the rival who invents later. But the reduced value of invention diminishes the incentive to invest in R\&D.

\section{Concluding remarks}

The U.S. has been under pressure from the international community to abandon the unique first-to-invent feature of its U.S. patent law. The opposition however remains strong in 
the U.S. One argument voiced by the opposition is that the first-to-invent feature of the U.S. law makes the U.S. the innovation powerhouse that it is and switch to the first-to-file rule, the international norm, will undermine innovation. In this paper we examine this claim in a stochastic model of R\&D competition. Our findings render some support to the opposition's argument.

Our results are derived under some simplifying assumptions. First, the improvement of the invention takes one period to complete. If it takes more than one period, that increases the risk of losing the invention to the rival who invents later but files earlier. Thus, first-to-file would prompt the firm more to file immediately for a patent. We thus believe that relaxing the one-period-wait assumption will not change our result and is more likely to strengthen it.

Another simplifying assumption we make is that the operating cost is constant at $\mathrm{c}$. Should it increase with investment in $R \& D$, maybe because a larger lab requires more maintenance cost, then that would make investment in R\&D less attractive. However, it would be unlikely to reverse our finding because one can invest just as much in first-to-invent as in first-to-file and still get greater profit due to the improvement. On the other hand, should the operating costs fall with $R \& D$ investment, perhaps because the greater investment in $R \& D$ the more efficient the lab is to operate daily, then it strengthens our case.

Finally, it is possible to reformulate our model in a continuous-time setting in the second stage. This extension has the advantage of avoiding simultaneous discoveries, but complicates the exposition. It however does not alter our qualitative result, provided that an inventor has to wait a fixed period to improve the invention. 


\section{Appendix}

\section{A. Proof of Proposition 2}

Write the first-order condition (3) as

$$
\begin{aligned}
& \mathrm{G}\left(\mathrm{p}_{\mathrm{A}}, \mathrm{p}_{\mathrm{B}}\right) \equiv\left(1-\mathrm{p}_{\mathrm{B}} / 2\right) \mathrm{M}\left[1-\delta\left(1-\mathrm{p}_{\mathrm{B}}\right)\right] \\
&+\delta \mathrm{c}-\left[1-\delta\left(1-\mathrm{p}_{\mathrm{A}}\right)\left(1-\mathrm{p}_{\mathrm{B}}\right)\right]^{2} \mathrm{k}^{\prime}\left(\mathrm{p}_{\mathrm{A}}\right)=0
\end{aligned}
$$

Recall that the best-response function is denoted by $r_{1}\left(p_{B}\right)$. Similarly, write the first-order condition (6) by

$$
\begin{aligned}
\mathrm{H}\left(\mathrm{p}_{\mathrm{A}}, \mathrm{p}_{\mathrm{B}}\right) \equiv \mathrm{m}\left(1-\mathrm{p}_{\mathrm{B}} / 2\right)\left[1-\delta\left(1-\mathrm{p}_{\mathrm{B}}\right)\right] \\
+\delta\left(1-\mathrm{p}_{\mathrm{B}}\right) \mathrm{c}-\left[1-\delta\left(1-\mathrm{p}_{\mathrm{A}}\right)\left(1-\mathrm{p}_{\mathrm{B}}\right)\right]^{2} \mathrm{k}^{\prime}\left(\mathrm{p}_{\mathrm{A}}\right)=0,
\end{aligned}
$$

with the best-response function $\mathrm{r}_{0}\left(\mathrm{p}_{\mathrm{B}}\right)$. Set $\mathrm{p}_{\mathrm{A}}=\mathrm{r}_{0}\left(\mathrm{p}_{\mathrm{B}}\right)$ and take the difference:

$$
\begin{aligned}
& \mathrm{G}\left[\mathrm{r}_{0}\left(\mathrm{p}_{\mathrm{B}}\right), \mathrm{p}_{\mathrm{B}}\right]-\mathrm{H}\left[\mathrm{r}_{0}\left(\mathrm{p}_{\mathrm{B}}\right), \mathrm{p}_{\mathrm{B}}\right] \\
& =\left(1-\mathrm{p}_{\mathrm{B}} / 2\right)\left[1-\delta\left(1-\mathrm{p}_{\mathrm{B}}\right)\right](\mathrm{M}-\mathrm{m})+\delta \mathrm{p}_{\mathrm{B}} \mathrm{c}>0
\end{aligned}
$$

for $\mathrm{p}_{\mathrm{B}}>0$. Since $\mathrm{H}\left[\mathrm{r}_{0}\left(\mathrm{p}_{\mathrm{B}}\right), \mathrm{p}_{\mathrm{B}}\right]=0$ by definition, the inequality implies $\mathrm{G}\left[\mathrm{r}_{0}\left(\mathrm{p}_{\mathrm{B}}\right), \mathrm{p}_{\mathrm{B}}\right]>0$. Given that $\mathrm{G}\left[\mathrm{r}_{1}\left(\mathrm{p}_{\mathrm{B}}\right), \mathrm{p}_{\mathrm{B}}\right]=0$ and concavity of $\mathrm{G}$ with respect to $\mathrm{p}_{\mathrm{A}}$ (the second-order condition), we conclude that $r_{1}\left(p_{B}\right)>r_{0}\left(p_{B}\right)$, i.e., A's best-response function lies further out when both inventors improve the inventions than when both file for a patent on discovery. The same holds true for B. Proposition 2 follows. 


\section{B: Proof of Lemma 1}

Focus on the symmetric mixed-strategy equilibrium. Suppose that, having made a discovery in period $t$, an inventor files immediately with probability $\lambda_{t} \in[0,1]$. In period 1 , when $A$ files, $A$ expects to get

$$
\mathrm{p}_{\mathrm{B}}\left[\lambda_{1} \mathrm{~m} / 2+\left(1-\lambda_{1}\right) \mathrm{m}\right]+\left(1-\mathrm{p}_{\mathrm{B}}\right) \mathrm{m}
$$

This has the following interpretation. With probability $p_{B} B$ also makes a discovery in $t=1$, and files for a patent in period 1 with probability $\lambda_{1}$, which yields $\mathrm{m} / 2$ to $\mathrm{A}$. If B does not file immediately, a probability- $\left(1-\lambda_{1}\right)$ event, A gets $\mathrm{m}$. In addition, with probability $1-\mathrm{p}_{\mathrm{B}} \mathrm{B}$ does not make the discovery in $\mathrm{t}=1$, so A gets $\mathrm{m}$. On the other hand, by improving the invention $\mathrm{A}$ gets

$$
\mathrm{p}_{\mathrm{B}}\left(1-\lambda_{1}\right) \mathrm{M} / 2+\left(1-\mathrm{p}_{\mathrm{B}}\right)\left\{\mathrm{p}_{\mathrm{B}} \lambda_{2} \mathrm{M} / 2+\mathrm{p}_{\mathrm{B}}\left(1-\lambda_{2}\right) \mathrm{M}+\left(1-\mathrm{p}_{\mathrm{B}}\right) \mathrm{M}\right\}
$$

In this case, $B$ makes a discovery with probability $p_{B}$ and improves the invention with probability $1-\lambda_{1}$, thereby yielding $\mathrm{M} / 2$ to A (If B files in $t=1$, A gets zero for payoff). This explains the first term. The second term represents the profit to A if B does not discover the invention in $t=1$. In that case, $B$ still has the chance of making a discovery in period 2 . If it does make a discovery, $B$ files for a patent right away with probability $\lambda_{2}$, which yields $M / 2$ to A, or improves the invention with probability $\left(1-\lambda_{2}\right)$, yielding $M$ to A. Lastly, if B does not make a discovery in $t=2$, A gets $M$. When $A$ adopts a mixed-strategy in $t=1$, these two payoffs must be equal.

Similarly, for $\mathrm{t} \geq 2$, the profit from filing immediately 


$$
\mathrm{p}_{\mathrm{B}}\left(1-\lambda_{\mathrm{t}-1}\right) \mathrm{m} / 2+\left(1-\mathrm{p}_{\mathrm{B}}\right)\left\{\mathrm{p}_{\mathrm{B}}\left[\lambda_{\mathrm{t}} \mathrm{m} / 2+\left(1-\lambda_{\mathrm{t}}\right) \mathrm{m}\right]+\left(1-\mathrm{p}_{\mathrm{B}}\right) \mathrm{m}\right\}
$$

$(t \geq 2)$ equals that from improving the invention:

$$
\left(1-\mathrm{p}_{\mathrm{B}}\right)\left\{\mathrm{p}_{\mathrm{B}}\left(1-\lambda_{\mathrm{t}}\right) \mathrm{M} / 2+\left(1-\mathrm{p}_{\mathrm{B}}\right)\left\{\mathrm{p}_{\mathrm{B}}\left[\lambda_{\mathrm{t}+1} \mathrm{M} / 2+\left(1-\lambda_{\mathrm{t}+1}\right) \mathrm{M}\right]+\left(1-\mathrm{p}_{\mathrm{B}}\right) \mathrm{M}\right\}\right\}
$$

Compared with (B1), (B3) has the extra term (first term) because in period $t \geq 2$ with positive possibility B files for a patent on the invention it discovered in period $\mathrm{t}-1$.

Now consider a class of mixed strategies in which firms mix in the first $\mathrm{n}$ periods and

choose to improve the invention for $\mathrm{t}>\mathrm{n}$. Let $\overline{\mathrm{p}}_{\mathrm{m}}(\mathrm{n})$ denote the symmetric equilibrium level of investment in $R \& D$. For example, for $n=1$, letting $\lambda_{2}=0$ in (B2) and equating it to (B1) yields

$$
\mathrm{p}_{\mathrm{B}}\left(1-\lambda_{1} / 2\right) \mathrm{m}+\left(1-\mathrm{p}_{\mathrm{B}}\right) \mathrm{m}=\mathrm{p}_{\mathrm{B}}\left(1-\lambda_{1}\right) \mathrm{M} / 2+\left(1-\mathrm{p}_{\mathrm{B}}\right)\left(1-\mathrm{p}_{\mathrm{B}} / 2\right) \mathrm{M}
$$

This determines the equilibrium $\lambda_{1}=\lambda_{1}{ }^{*}$. The total expected profit to $\mathrm{A}$ is

$$
\begin{aligned}
& {\left[\mathrm{p}_{\mathrm{B}}\left(1-\lambda_{1}\right) \mathrm{M} / 2+\left(1-\mathrm{p}_{\mathrm{B}}\right)\left(1-\mathrm{p}_{\mathrm{B}} / 2\right) \mathrm{M}-\mathrm{c}\right]} \\
& +\delta\left(1-\mathrm{p}_{\mathrm{A}}\right) \frac{p_{A}\left(1-p_{B} / 2\right) M-\left[1+\delta p_{B}\left(1-p_{A}\right)\right] c}{1-\delta\left(1-p_{A}\right)\left(1-p_{B}\right)}-k\left(p_{A}\right) .
\end{aligned}
$$

The first-order condition is

$$
\begin{aligned}
& \delta\left(1-\mathrm{p}_{\mathrm{A}}\right)\left\{\left(1-\mathrm{p}_{\mathrm{B}} / 2\right) \mathrm{M}\left[1-\delta\left(1-\mathrm{p}_{\mathrm{B}}\right)\right]+\delta \mathrm{c}\right\}-\left[1-\delta\left(1-\mathrm{p}_{\mathrm{A}}\right)\left(1-\mathrm{p}_{\mathrm{B}}\right)\right]^{2} \mathrm{k}^{\prime}\left(\mathrm{p}_{\mathrm{A}}\right) \\
& =0 .
\end{aligned}
$$

A comparison with (6) indicates that the best-response function implicitly given by the above condition lies strictly inside $r_{1}\left(p_{B}\right)$. Thus, we can then find the symmetric equilibrium probability $\bar{p}_{m}(1)$, which is less than $p_{1}$ * Continuing this way, we can compute $\bar{p}_{m}(n)$ for each 
$\mathrm{n}$ and can show that $\overline{\mathrm{p}}_{\mathrm{m}}(\mathrm{n})$ is a decreasing sequence. Since the sequence is bounded it converges, say, to $\overline{\mathrm{p}}_{\mathrm{m}}$ * Similarly, let $\underline{\mathrm{p}}_{\mathrm{m}}(\mathrm{n})$ be the equilibrium investment in $\mathrm{R} \& \mathrm{D}$ in a game in which firms commit to randomizing for the first $\mathrm{n}$ period switching to filing immediately without improvement. Then, $\underline{p}_{m}(1)>p_{0}^{*}$ and $\underline{p}_{m}(n)$ is an increasing sequence. Since it is bounded, this sequence converges, say, to $\underline{p}_{m}^{*}$. It is also readily shown that $\underline{p}_{m}(n)<\bar{p}_{m}(n)$. Thus, $\underline{\mathrm{p}}_{\mathrm{m}}^{*}=\overline{\mathrm{p}}_{\mathrm{m}}^{*}=\mathrm{p}_{\mathrm{m}}^{*}$. Therefore, $\mathrm{p}_{1}^{*}>\mathrm{p}_{\mathrm{m}}^{*}>\mathrm{p}_{0}^{*}$. 


\section{References}

Aoki, Reiko, and Thomas Prusa, 1996, Product development and the timing of information disclosure under U.S. and Japanese patent systems, Journal of the Japanese and International Economics 10, 233-249

Aoki, Reiko, and Yossi Spiegel, 2003, Pre-grant patent publication, R\&D, and welfare, unpublished paper

Cohen, L. R., and Ishii, J., 2005, Competition, innovation, and racing for priority at the U.S. Trademark and Patent Office, AER-Brookings Joint Center for Regulatory Studies Working Paper 05-22.

Cornelli, F., and M. Schankerman, 1999. Patent renewals and R\&D incentives, RAND Journal of Economics 30, 197-213.

Gilbert, R., and Carl Shapiro, 1990, Optimal patent length and breath, RAND Journal of Economics 21, 106-113.

Graham, Stuart J. H., and David C. Mowrey, 2004, Submarines in software? Continuations in US software patenting in the 1980s and 1990s, Economics of Innovation and New Technology 13, 443-456

Kingston, William, 1992, Is the United States right about 'first to invent'? European Intellectual Property Review 7, 223-226.

Klemperer, Paul, 1990. How broad should the scope of patent protection be? RAND Journal of Economics 21, 113-130.

Nordhaus, William, 1969, Invention, growth and wealth, Cambridge, Mass: MIT Press 
Lerner, Josh, 2003, The patent system and competition, a statement to the Federal Trade Commission/Department of Justice hearings on competition and intellectual property law and policy in the knowledge-based economy, www.ftc.gov/opp/intellect/lernerjosh.pdf

O’Donoghue, T., Scotchmer and Thisse, 1998, Patent breadth, patent life, and the pace of technological progress, Journal of Economics and Management Strategy 7, 1-32

Scotchmer, Suzanne, 1999, On the optimality of the patent renewal system, RAND Journal of Economics 36, 181-196.

Scotchmer Suzanne, and Jerry Green,1990. Novelty and discloser in patent law, RAND Journal of Economics 21, 131-146

Stephenson, C. E., 2005, Will patent reform become a reality, Lawyers Weekly USA, May 23. 


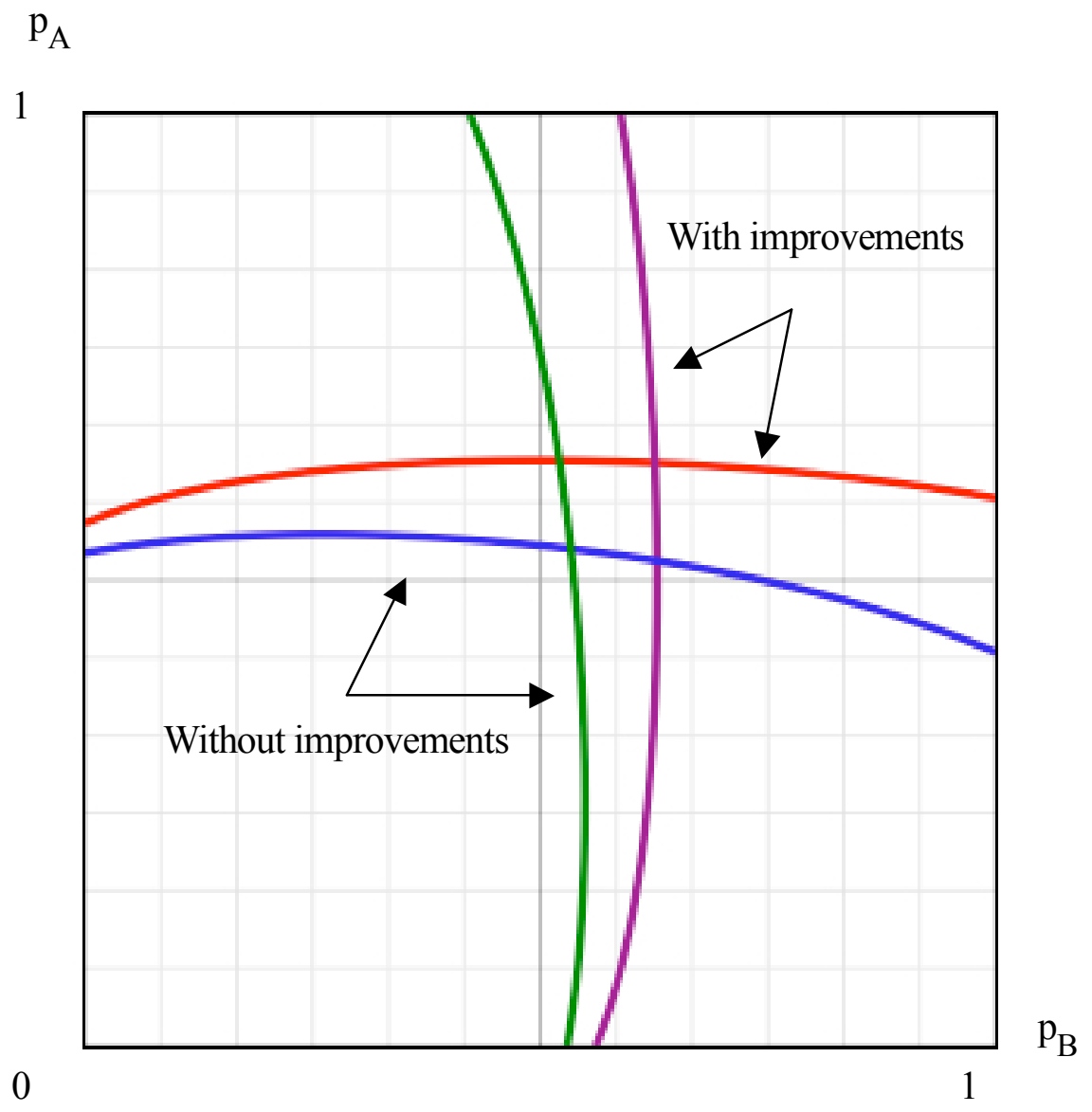

